\title{
Studies on ethnomedicinal plants of Nimar-ecoregion of Madhya Pradesh
}

\author{
S.K.Mahajan $\varpi^{1}$, Tripta Sapru ${ }^{2}$ and Bharti Khare ${ }^{3}$
}

Received: 21.08.2012

Revised: 25.10 .2012

Accepted: 15.01.2013

\begin{abstract}
The present communication deals with the ethnomedicinal plants used by the tribal communities Maheshwar tehsil situated in Khargone district of Nimar-ecoregion, M.P. In all 116 plant species belonging to 92 genera are collected, out of which 26 angiospermic species belonging to18 families are found to be used by the tribal people of this area to cure various human ailments.
\end{abstract}

Keywords: Flora, vegetation, human ailments, Khargone district, Maheshwar tehsil

\section{Introduction}

Maheshwar is one of the biggest tehsils of Khargone district of M.P. It is situated in the extreme South-West part of Madhya Pradesh state. Before independence major part of Holkar state and a part of Dewas state was included in this tehsil. Biogeographically this area comes under Central India. The biodiversity, of this area is quite rich which is probably due to the wide variation in climate, rainfall, extremes of temperatures and presence of a part of Vindhyachal mountain in this region. This tract is inhabited by three main tribes namely Darbari bhilala, Rathiya bhilala and Barela bhil. Each of these tribes has its own identity and dialect. These people are very rich in their culture and cultural herbal medicines etc are a component of tribal culture. They offer an excellent scope to study the indigenous knowledge of ethnobiodiversity in the region under investigation. In past four decades ethnobotanical research work has been carried out in various parts of India (Jain, 1995 \& 1999; Maheshwari,1963; Maheshwari et al ,1981 ). As regards Madhya Pradesh state sufficient amount of ethnobotanical work has been done in various districts namely Bastar, Balaghat, Jabalpur and Chhindwara (Jain1977; Sahu,1982). In Nimar ecoregion a little research work has been done

\footnotetext{
Author's Address

${ }^{1}$ Former Professor of Botany, Govt.P.G.College, Khargone, M.P India

${ }^{2}$ Botany Department, Govt. Girls College, Ujjain, M.P

${ }^{3}$ Botany Department, Govt.MLB Girls College, Bhopal, M.P. E-mail: shrikrishna.mahajan@gmail.com
}

(Shastri, 1977; Solanki, 1984; Mahajan \& Patel, 2003). The present work deals with some ethnomedicinal plants collected from Maheshwar tehsil of Khargone district which comes under Nimar ecoregion of M.P.

\section{Material and Methods}

The present survey was done during the year 201011 and in this connection various tribal villages of Maheshwar tehsil which were visited are Jhapri, Chunariya, Karandiya, Moganwa, Kamadiya and Devpipaliya. The plants used by the tribal people to cure various human diseases were noted with the help of old tribal medicine men "barwa" and other experienced persons.Herbarium sheets were prepared and identification of the plants was done with the help of standard flora and literature ( Kirtikar \& Basu,1935; Chopra et al, 1956; Cooke, 1957, Mudgal et al 1997; Singh et al, 2001; Verma et al, 1993; Shah,1978; Naik,1998).The herbarium sheets are deposited in the Botany Department of Govt. P.G.College, Mandleshwar. List of ethnomedicinal plant species together with their families is shown in Table 1.

\section{Results and Discussion}

Earlier to this investigation, Tenguria et al (2006) mentioned in their studies about the smooth muscle relaxant activity of herbal drugs from Dolichos lablab. Punjani (2006) has reported 35 plant species that are used traditionally for the treatment of various human ailments and disorders, such as skin 
diseases, colic complaints, headache, fever, piles, asthma, jaundice, diarrhea, dysentery, vomiting wounds etc. Sarvalingam and Rajendran (2012) have reported 60 species of lianas belonging to 47 genera of 18 fmilies from Manthamalai hills of Southern-Western Ghats of India and concluded that areas with density of small trees had high lians density and areas with a high number of trees saplings had a relatively high density of climbing lianas. Patel (2010) has surveyed the medicinal plants of different rural and forest areas of Betul district of Madhya Pradesh and found that 7 plant species i.e. Aegle marmelos, Allium сера, Asparagus racemosus, Bryophyllum calycinum, Cuscuta reflexa,Euphorbia pulcherrima and Ficus glomerata ) belonging to 6 families are used by tribal local nhabitants and folk practioners for the treatment of diarrhea and dysentery.Recently Agnihotri and Bhatnagar (2013) have made an effort to enlist 8 plant species belonging to 6 families of Pteridophytes from Kanpur and adjacent areas which possess medicinal utility and suggested for their preservation and conservation.Rathore (2013) has also published a review article on"Indigenous medicinal plants and natural herbal products in India" in which he has stated that over the past few years the medicinal plants have however regained a wide recognition due to an escalating faith in herbal medicine in view of its lesser side effects as compared to allopathic medicine besides the necessity of meeting the requirements of medicine for an increasing human population. From Table 1, it is revealed that out of a total of 116 plant species collected, 26 species were found to be used by the tribal people to cure various human ailments in this area. Some of these important plant species used by

\section{Table 1. List of plant species collected from Maheshwar tehsil situated in Nimar eco-region of} Madhya Pradesh

\begin{tabular}{|c|c|c|c|c|}
\hline S.No. & Scientific name of the plant & Local name & Family name & Plant part used \\
\hline 1 & Achyranthes aspera L. & Hathijhara & Amarantaceae & Stem \\
\hline 2 & Adhatoda vasica Nees. & adusa & Acanthaceae & leaves \\
\hline 3 & Barleria prionitis L. & Pila katasla & Acanthaceae & leaves \\
\hline 4 & Bauhiniavariegate L. & kachnar & Caesalpiniaceae & Bark \\
\hline 5 & Boerhaavia diffusa L. & Punarnava & Nyctaginaceae & Leaves \\
\hline 6 & Bryonia laciniosa L. & Shivlingi & Cucurbitaceae & Seeds \\
\hline 7 & Butea frondosa Roxb, & Palas & Fabaceae & Fresh seeds \\
\hline 8 & Cardiospermum helicacabum L. & Phugga & Sapindaceae & Entire plant \\
\hline 9 & Cissus quadrangularis L. & Harjor & Vitaceae & Stem \\
\hline 10 & Cocculus hirsutus (L) Diels. & Jaljamni & Menispermaceae & Leaves \\
\hline 11 & Echinops echinatus Roxb. & Unt-katara & Asteraceae & Entire plant \\
\hline 12 & Enicostoma axillare L. & Chhota chirayta & Gentianaceae & Entire plant \\
\hline 13 & Holarhhena antidysenterica Wall. & Kuda & Apocynaceae & Seeds \\
\hline 14 & Merremia emerginata Hook f. & Undri-ka-chara & Convolvulaceae & Leaves \\
\hline 15 & Ocimum basilicum L. & Jangli tulsi & Lamiaceae & Entire plant \\
\hline 16 & Pergularia daemia(Forsk.)Chier. & Utran & Asclepiadaceae & Leaves \\
\hline 17 & Peristrophe bicalyculata Nees. & Utran & Acanthaceae & Entire plant \\
\hline 18 & Solanum virginianum L. & Pili kateri & Solanaceae & Entire plant \\
\hline 19 & Tectona grandis $\mathrm{L}$. & Sagon & Verbenaceae & Stem bark \\
\hline 20 & Tephrosea purpurea (L) Pers. & Sarponkha & Fabaceae & Root \\
\hline 21 & Tinospora cordifolia L. & Gurwel & Menispermaceae & Leaves \\
\hline 22 & Tridax procumbens L. & Kulhara & Asteraceae & Leaves \\
\hline 23 & Triumfetta rhomboidea Jacq. & Gadar lapti & Tiliaceae & Leaves \\
\hline 24 & Vernonia cinaria Less. & Bhringraj & Asteraceae & Entire plant \\
\hline 25 & Vitex negundo L & Nirgundi & Verbenaceae & Leaves \\
\hline 26 & Withania coagulans ( Stock) Dunal. & Asagandh & Solanaceae & Leaves, root \\
\hline
\end{tabular}

the tribal people are mentioned here: Cocculus Roxb.(=Butea monosperma (Lam.).Taub.) (in colic hirsutus (L.) Diels.(in leucorrhoea), Butea frondosa pain), Merremia tridentata Hallier (in urinary 
problems), Cissus quadrangularis L. (in sprains and bone problems), Solanum virginianum L. ( in joints pain ) and Adathoda vasica L. (in cough trouble ).Enicostoma axillarel.(in Sciatica), Vernonia cinaria Less.(in fever), Bauhinia variegate L.( in fractures), Boerhaavia diffusa L.

(in kidney trouble ), Tinospora cordifolia L.(in stone trouble ), Withania coagulans (Stock ) Dunal. (in tension), Tephrosia purpurea (L.) Pers. (in leucorrhoea), Pergularia daemia (Forsk. Chier.(in urino-genital septic conditions) and Tridax procumbens L. (in wounds and cuts). Echinops echinata Roxb.(hypertension), Eclipta alba L. (skin disease), Holarrhena antidysenterica Wall. (in dysentery), Bryonia laciniosa L.(in fertility), Triumfetta rhomboidea Jacq. (in hornia) and Barleria prionitis L.(in toothache) Besides this, some animals are also used to cure human diseases i.e. Cow (urine used in epilepsy), Goat (milk is used tuberculosis), Hare (meat is used in chicken pox) and Python (for insanity and other neurobial problems). There is an urgent need for the protection and conservation of these valuable plant and animal species. It is strongly believed that some of these folklore plants and animals might prove to be life saving and lead to effective drugs through detailed investigation by scientific techniques in future.

\section{Acknowledgements}

The authors are grateful to the Principals of Govt. P.G.College, Khargone, Madhya Pradesh for encouragement and providing library facilities and also to Shri Jaiprakash and Lalit of Jhapri village for helping in plant collection work.

\section{References}

Agnihotri, Nikhil and Bhatnagar Santosh 2013. Medicinal Pteridophytes of Kanpur and adjacent areas, 3rd National Conference on" Innovations in Indian Sciences, Engineering and Technology" organized by SSMD, CSIR- NPL,and IARI, New Delhi., abst. pp. 54

Chopra, R.N., S.L.Nayar \& I.C.Chopra.1956, Glossary of Indian Medicinal Plants, C.S.I.R. Publication, New Delhi.

Cooke, T.,1955, Flora of the presidency of Bombay ,BSI Publication, Calcutta India,Vol. I-II

Jain S.K. \& Goel A.K., 1995, A manual of Ethno botany ,edited by Jain S.K., Scientific Publishers, Jodhpur, India.
Jain,S.K.\& Mudgal,V.A. 1999, Handbook of Ethnobotany, Bisen Singh Mahendra Pal Singh Publication, Dehradun, India

Jain, S. K. \& Rao , R. R., 1977, Handbook of field Herbarium methods ,oxford and IBH Publishing company ,New Delhi, India.

Kirtikar,K.R. \& B.D.Basu, 1935,. Indian Medicinal Plants,Lalit Mohan Basu, Allahabad.

Mahajan,S.K. \& Patel,P.2003, A preliminary survey of anthelmintic plants used by the tribes of West Nimar district of Madhya Pradesh, In: $12^{\text {th }}$ Annual Conference of IAAT and National Seminar on Plant Taxonomy in National Development, Plant Diversity,Human Welfare and Conservation (eds.) M.K.Janarthanan and D.Narsimhan, 289-292

Maheshwari,J.K., Singh,K.K. \& Saha,S. 1981, The Ethnobotany of Tharus of Kheri district,U.P.,Economic Botany Information Service,N.B.R.I., Lucknow,

Maheshwari,J. K.1963, The Flora of Delhi, CSIR, Delhi.

Mudgal, V., Khanna, K. K. \& Hajra, P. K., 1997, Flora of Madhya Pradesh , Vol.2.BSI Publication, Calcutta, India.

Naik, V.N., 1998, Flora of Marathawara District,Amrut Prakashan Aurangabad M.S.India,

Patel,Sapan 2010 Traditional use of indigenous plants in Betul district of Madhya Pradesh to cure diarrhea and dysentery. Environment Conservation Journal, 11 (3):pp19-22.

Punjani, Bhasker, L. 2006 Ethno- medicobotanical study of Kathodi tribe of Sabarkanth in Gujarat, Ethnobotany,Vol. 18, pp. 135-138

Rathire,Ashok 2013,. Indigenous medicinal plants and natural herbal products in India: A review, Third National Conference on" Innovations in IndianSciences, Engineering and Technology” organized by SSMD, New Delhi., abst. Pp. 65-66.

Sahu, T.R., 1982, Ancient Science of Life, 1(3):178-181.

Sarvalingam,A. \& Rajendran,A. 2012 Diversity of Lianas in Maruthhamalai hills of Southern-Western Ghats , India, Phytotaxonomy,Vol. 12: ,pp. 131-135.

Shah, G.L.,1978, Flora of Gujrat State, Sardar Patel University Vallabh Vindya Nagar, Gujrat, India.

Shastri,M.B. 1977, Flora of Khargone,Madhya Pradesh: Recent Trends and Contacts between Cytogenetics, Embryology andMorphology,445454.

Singh, N.P., Khanna, K. K.,. Mudgal, V., \& Dixit, R.D., 2001, Flora of Madhya Pradesh, BSI Publication, Calcutta, India., Vol. III.

Solanki,C.M. 1984, Flora of Indore, Ph.D. Thesis, Devi Ahilya Vishwavidyalaya, Indore

Tenguria,R.K., Patel,S., \& Saxena,R.C. 2006Smooth relaxant activity of herbal drugs from Dolichos lablab. Flora and Fauna, Vol. 12(1):129-132.

Verma, D.M., Balakrishnan \&Dixit, R. D., 1993, Flora of Madhya Pradesh ,BSI Publication Calcutta India., Vol. I 